\title{
Microleakage Evaluation in Class V Cavities Restored with Five Different Resin Composites: In vitro Dye Leakage Study [Corrigendum]
}

Bajabaa S, Balbaid S, Taleb M, Islam L, Elharazeen S, The authors apologize for this error. Alagha E. Clin Cosmet Investig Dent. 2021;13:405-411.

The authors have advised there is an error in the author list on page 405. The author name "Shaza Balbaid" should read "Shatha Balbaid".

\section{Publish your work in this journal}

Clinical, Cosmetic and Investigational Dentistry is an international, peer-reviewed, open access, online journal focusing on the latest clinical and experimental research in dentistry with specific emphasis on cosmetic interventions. Innovative developments in dental materials, techniques and devices that improve outcomes and patient satisfaction and preference will be highlighted. The manuscript management system is completely online and includes a very quick and fair peer-review system, which is all easy to use. Visit http://www.dovepress.com/testimonials.php to read real quotes from published authors. 